\section{Alternative Management of Roadside Vegetation}

\author{
Allen V. Barker ${ }^{1,3}$ and Randall G. Prostak ${ }^{2}$
}

AdDitional INDEX WORDS. acetic acid, citric, clove oil, corn gluten meal, pelargonic, glufosinate-ammonium, glyphosate, mulch

SUMMARY. Management of vegetation is an important element of roadside maintenance for safety and aesthetics. Current methods of management by highway departments principally involve mowing and the use of conventional, chemical herbicides. This research addressed use of herbicides (citric acid, clove oil, corn gluten meal, and pelargonic acid) that are considered as alternatives to conventional herbicides and the use of mechanical treatments of woodchip and bark mulches and burning. These alternative methods were compared with the use of conventional herbicides to assess the relative efficacy of treatments on roadside sites. A single application of pelargonic acid demonstrated immediate or short-term suppression of growth of vegetation; however, the efficacy lasted for no more than 6 weeks, after which regrowth was not distinguishable from untreated vegetation. Repeated applications of pelargonic acid will be necessary for season-long efficacy. Formulations of citric-acetic acid gave no control or only weak suppression of vegetative growth soon after application, and no suppression was evident after 6 weeks, suggesting that these materials have only limited use in roadside environments. The effects of burning lasted for about 6 weeks. No suppression of growth of roadside vegetation occurred with the use of corn gluten meal, which acted as a nitrogen fertilizer to promote growth. Mulches of bark or woodchips were strongly suppressive against emerging vegetation for 2 years, but were more effective in the first year than in the second year after application. The costs of materials and labor for the alternative practices were substantially more than for the conventional herbicides used in this study.

$\mathrm{T}$ he management of vegetation is an important element of roadside maintenance for safety and aesthetics to produce a healthy roadside environment. Johnson (2000) noted that a healthy roadside environment is one that limits maintenance needs and costs, preserves the roadside surface, provides safety for travelers and vehicles, limits the liability of governmental agencies, maintains good public relations, and improves the driving experience. Methods of management to produce this environment include cultural, biological, mechanical, and chemical procedures for weed control. Cultural procedures, such as growing wildflowers or grasses, involve practices that promote the growth of desirable

This research was supported in part by a grant from the Massachusetts Highway Department (Boston, MA).

${ }^{1}$ Professor, Department of Plant, Soil, and Insect Sciences, University of Massachusetts, Amherst, MA 01003

${ }^{2}$ Extension Educator, University of Massachusetts Extension, University of Massachusetts, Amherst, MA 01003

${ }^{3}$ Corresponding author. E-mail: barker@pssci.umass. edu. plants that restrict the capacity of weeds to grow. Biological practices involve using insects, diseases, or even dense groundcover to control weeds (Eshenaur, et al., 2007; Stelljes and Wood, 2000; Weeden et al., 2008; Yandoc-Abeles et al., 2006a, 2006b). Mechanical methods, primarily mowing, but also including mulching, are the most widely used means of weed control on roadsides (Barker and Prostak, 2008). Chemical control involves the use of herbicides, growth regulators, or other growth retardants.
The use of herbicides provides much flexibility and low costs in control of vegetation, considering the equipment for application and the wide spectrum of materials that are available (Henderson, 2000). However, some of the public may not believe that herbicides are safe to use along roadsides (Owens, 1999). Consequently, state departments of transportation are looking into alternatives to conventional herbicides in weed management. Alternatives include chemical treatments with organic herbicides (Organic Materials Research Institute, 2008) and mechanical treatments, such as burning, steaming, or mulching (Barker and Prostak, 2008; Young, 2002, 2004).

One chemical alternative is to use herbicides that have little effect on the environment after weeds are killed or controlled. Several alternative herbicides are marketed as products to manage the growth of vegetation. These materials have an a.i. that is often of plant origin and include various by-products of food and feed processing and materials that are prepared particularly for their herbicidal activities (Duke, 1990; Tworkoski, 2002).

Corn gluten meal (CGM) has been evaluated in recent years as a plant by-product with herbicidal effects (Christians, 2007). The byproduct is the proteinaceous fraction of corn (Zea mays L.) grain and results from the milling process to make cornstarch and corn syrup; CGM is about $60 \%$ protein or about $10 \%$ nitrogen by weight (Christians, 2002). Peptides are the active constituents that inhibit root growth from germinating seeds (Liu and Christians, 1994; 1996).

\begin{tabular}{lllc}
\hline $\begin{array}{l}\text { Units } \\
\begin{array}{l}\text { To convert U.S. to SI, } \\
\text { multiply by }\end{array}\end{array}$ & U.S. unit & SI unit & $\begin{array}{l}\text { To convert SI to U.S., } \\
\text { multiply by }\end{array}$ \\
\hline 1.0551 & Btu & $\mathrm{kJ}$ & 0.9478 \\
7.8125 & $\mathrm{fl} \mathrm{oz} / \mathrm{gal}$ & $\mathrm{mL} \cdot \mathrm{L}^{-1}$ & 0.1280 \\
0.3048 & $\mathrm{ft}$ & $\mathrm{m}$ & 3.2808 \\
0.0929 & $\mathrm{ft}^{2}$ & $\mathrm{~m}^{2}$ & 10.7639 \\
3.7854 & $\mathrm{gal}$ & $\mathrm{L}$ & 0.2642 \\
2.54 & inch $(\mathrm{es})$ & $\mathrm{cm}$ & 0.3937 \\
0.4536 & $\mathrm{lb}$ & $\mathrm{kg}$ & 2.2046 \\
48.8243 & $\mathrm{lb} / 1000 \mathrm{ft}^{2}$ & $\mathrm{~kg} \cdot \mathrm{ha}^{-1}$ & 0.0205 \\
1.6093 & $\mathrm{mile}(\mathrm{s})$ & $\mathrm{km}$ & 0.6214 \\
305.1517 & $\mathrm{oz} / \mathrm{ft}^{2}$ & $\mathrm{~g} \cdot \mathrm{m}^{-2}$ & 0.0033 \\
6.8948 & $\mathrm{psi}$ & $\mathrm{kPa}$ & 0.1450 \\
0.9464 & $\mathrm{qt}$ & $\mathrm{L}$ & 1.0567 \\
101.8646 & $\mathrm{qt} / 1000 \mathrm{ft}^{2}$ & $\mathrm{~L} \cdot \mathrm{ha}^{-1}$ & 0.0098 \\
0.7646 & $\mathrm{yard}$ & $\mathrm{m}^{3}$ & 1.3080
\end{tabular}


Attention has been given to the organic acids, acetic acid (vinegar) (Johnson et al., 2004; Radhakrishnan et al., 2003; Webber and Shrefler, 2007; Young, 2004), and citric acid (Chase et al., 2004). These acids work as nonselective, contact, postemergence herbicides causing rapid desiccation of plant tissues. They are most effective at killing weeds when applied as a foliar spray at concentrations ranging $10 \%$ to $20 \%$ acetic acid, citric acid, or blends of the two and when the weeds are about 6 to 9 inches tall or less (Doll, 2002; Radhakrishnan et al., 2003). Generally, $80 \%$ to $100 \%$ control can be expected for small annual and perennial weeds, but perennial species with persistent root systems will begin to regrow within several weeks.

Pelargonic acid (nonanoic acid) is a naturally occurring fatty acid in the oil of geranium (Pelargonium L'Her.) (Coleman and Penner, 2006; Windholz, 1983). It is manufactured from other fatty acids to

Table 1. Alternative herbicides, conventional herbicides, mulches, and burning treatments applied in 2 years of investigation of management of roadside vegetation under guardrails in Expt. 1.

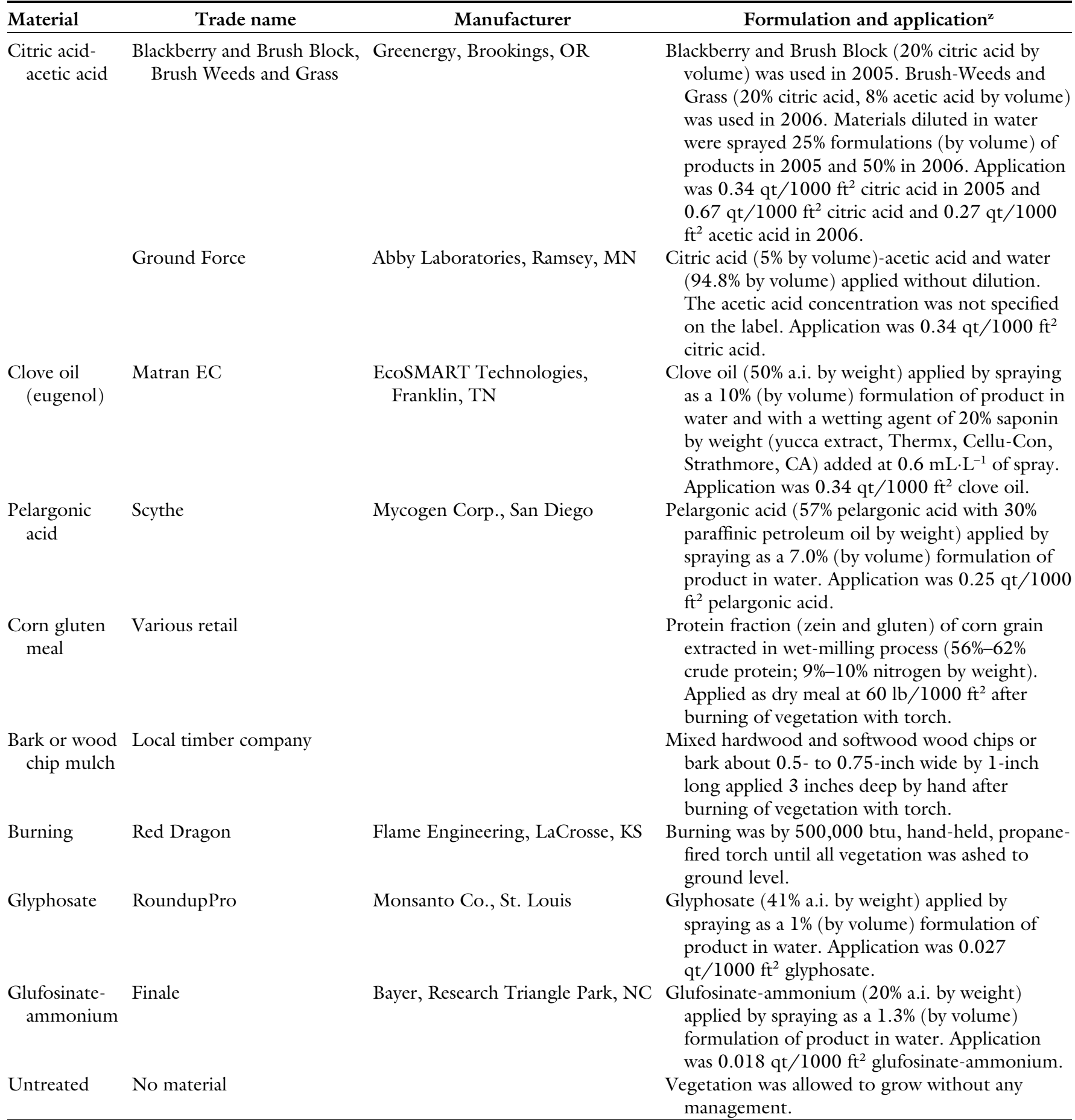

${ }^{2} 1 \mathrm{qt} / 1000 \mathrm{ft}^{2}=101.8646 \mathrm{~L} \cdot \mathrm{ha}^{-1}, \mathrm{l} \mathrm{mL} \cdot \mathrm{L}^{-1}=0.1280 \mathrm{fl} \mathrm{oz} / \mathrm{gal}, \mathrm{l} \mathrm{lb} / 1000 \mathrm{ft}^{2}=48.8243 \mathrm{~kg} \cdot \mathrm{ha}^{-1}, \mathrm{l}$ inch $=2.54 \mathrm{~cm}, 1 \mathrm{btu}=1.0551 \mathrm{~kJ}$ 
produce the commercially available product. Pelargonic acid is a nonselective contact herbicide that effectively controls annual broadleaf and grass weeds that are less than 6 inches high (Ayeni et al., 1999). Repeated applications may be required with large annual plants and perennials. It has also been investigated as a preharvest desiccant (Arboleya et al., 2005). Research on use along highways (Young, 2002) and in the other applications indicate that this material could be used for weed control on highways, such as for weeds growing in cracks and joints in pavement and curbing, near abutments, and under guardrails.

Clove oil, derived from the clove plant (Syzygium aromaticum Merr. \& Perry), is active against various organisms, including nematodes (Meyer et al., 2008), insects (Akhtar et al., 2008; Yang et al., 2004), microorganisms (Kishore et al., 2007; van der Wolf et al., 2008), and plants (Boyd and Brennan, 2006; Tworkoski, 2002), and may have potential for use in roadside environments.

Burning fields to reduce weed populations has been a historic practice for many years. However, burning has many obvious disadvantages, including air pollution, reduced visibility caused by smoke, and the chance of uncontrolled fire. Most flamebased equipment is fueled by lowpressure gas (LPG) or propane gas. Burner-type weeders deliver heat energy to the plants directly by close contact to a flame. Ascard (1994, 1995 ) and Rifai et al. (2002) reported that weeds with thin leaves and unprotected growing points were more susceptible to burning than grasses and other species with protected growing points. All species were most susceptible to burning when small (0-4 true leaves) compared with larger plants (6-12 true leaves), and significantly more heat energy was needed to control the larger plants.

Covering the soil with a mulch of an organic layer or of a barrier, such as plastic or landscape fabric, has potential use in roadside weed control in small areas where herbicides are often used such as around sign posts, along fence rows, and under guardrails. The weed-control function of mulches is based on the blocking of sunlight from the plants or on the presentation of a barrier through which the weeds cannot emerge (Barker and Bhowmik, 2001; Barker and O'Brien, 1995).

This research investigated the use of CGM, acetic-citric acid blends, pelargonic acid, clove oil, mulches, and burning as alternative practices for management of vegetation under guardrails along a highway in Massachusetts. In assessments of their efficacies, these practices were compared with use of conventional herbicides of glyphosate and glufosinateammonium. Mowing of vegetation was also investigated for its effects on the efficacy of herbicides.

\section{Materials and methods}

Two experiments were conducted on the roadside of Interstate 91 in Deerfield, MA.

EXPERIMENT 1. The first experiment was conducted at the weigh station beside the northbound lane past Exit 24 and investigated several alternative herbicides and mechanical treatments for management of vegetation under guardrails (Table 1 ). The research was conducted in 2005 and in 2006 with individual treatments, except for mulches, being applied to the same plots in each year. Plots were $4 \mathrm{ft}$ wide by $20 \mathrm{ft}$ long under guardrails along the highway. Treatments were applied in mid-June of each year with three replications in a randomized-complete-block design. The site was sprayed with glyphosate (RoundupPro; Monsanto, St. Louis) by the Massachusetts Highway Department in 2004, the year before this experiment was conducted. Therefore, most of the vegetation in the plots emerged in the year of application of the herbicides. The principal vegetation on this site was a mixture of annual grasses and annual broadleaf plants, principally crabgrass (Digitaria sanguinalis Scop.), spiny sowthistle (Sonchus asper Hill), rabbit-foot clover (Trifolium arvense L.), and lambsquarters (Chenopodium album $\mathrm{L}$.). The grasses were less than 2 inches tall; the broadleaf weeds were about 4 inches tall, and all plants had about four true leaves.

Sprayed herbicides (Table 1) were applied with $1.5 \mathrm{~L}$ of herbicide-water mix to wet the vegetation of three plots $\left(240 \mathrm{ft}^{2}\right)$. The sprayer was a standard, diaphragm unit (model 485; Solo, Newport News, VA) operating at $60 \mathrm{psi}$ and equipped with a flat-spray tip (TeeJet XR, $110^{\circ}$; TeeJet Technologies, Springfield, IL). Mulches of bark or woodchips were applied only in 2005 and in duplicates within blocks with one plot of the pair to be sprayed with an alternative herbicide (clove oil) after emergence of vegetation through the mulch. The treatment of spraying the mulches with an alternative herbicide was included to assess the necessity of a supplemental treatment to restore the efficacy and appearance of mulched areas, especially in years following the initial application. Mulches were applied 3 inches deep to plots that had been burned to remove vegetation. The supplemental spray treatment did not occur in 2005 because weed growth through mulches was insufficient to require the supplement. In 2006, a spray treatment of clove oil (Matran EC;

Table 2. Descriptions of visual indices (0-10 scale) used in scoring the efficacy of alternative treatments in control of vegetation in roadside plots under guardrails.

\begin{tabular}{|c|c|}
\hline $\begin{array}{l}\text { Index } \\
\text { score }\end{array}$ & Description of score \\
\hline 0 & No control of vegetation. \\
\hline 1 & $\begin{array}{l}\text { Less than } 10 \% \text { of vegetation } \\
\text { controlled. }\end{array}$ \\
\hline 2 & $\begin{array}{l}10 \% \text { to } 20 \% \text { of vegetation } \\
\text { controlled. }\end{array}$ \\
\hline 3 & $\begin{array}{l}20 \% \text { to } 30 \% \text { of vegetation } \\
\text { controlled. }\end{array}$ \\
\hline 4 & $\begin{array}{l}30 \% \text { to } 40 \% \text { of vegetation } \\
\text { controlled. }\end{array}$ \\
\hline 5 & $\begin{array}{l}40 \% \text { to } 50 \% \text { of vegetation } \\
\text { controlled. }\end{array}$ \\
\hline 6 & $\begin{array}{l}50 \% \text { to } 60 \% \text { of vegetation } \\
\text { controlled. }\end{array}$ \\
\hline 7 & $\begin{array}{l}60 \% \text { to } 70 \% \text { of vegetation } \\
\text { controlled. }\end{array}$ \\
\hline 8 & $\begin{array}{l}70 \% \text { to } 80 \% \text { of vegetation } \\
\text { controlled. }\end{array}$ \\
\hline 9 & $\begin{array}{l}80 \% \text { to } 90 \% \text { of vegetation } \\
\text { controlled. }\end{array}$ \\
\hline 9.5 & $\begin{array}{l}\text { A special rating used } \\
\text { when more than } 90 \% \text { of } \\
\text { the vegetation was } \\
\text { controlled with only one } \\
\text { or two live plants } \\
\text { remaining in a plot. }\end{array}$ \\
\hline 10 & $\begin{array}{l}\text { This rating was applied } \\
\text { when all of the vegetation } \\
\text { was killed or if no } \\
\text { regrowth occurred at the } \\
\text { time of the rating. }\end{array}$ \\
\hline
\end{tabular}


EcoSmart, Franklin, TN) in the same amounts as that applied to the clove oil-treated plots (Table 1) was applied to the one of each pair of the mulched plots after emergence of vegetation through the mulches (about July 1). Clove oil was chosen as the supplemental treatment because it is an OMRI-listed (Organic Materials Review Institute, Eugene, OR) alternative herbicide and exhibited some potential for weed control (Barker and Prostak, 2008). CGM was applied by surface application to plots that had been flamed to remove vegetation. Preliminary research in a greenhouse (Barker and Prostak, 2008) and other research (Young, 2002) showed no differences in efficacy between surface-applied and soil-incorporated CGM. In each randomized block, one plot received no treatment and served as a control.

Conditions of weed populations and appearance under guardrails were rated by visual indexing (Table 2) during June, July, August, and September. In late September when growth had ended due to senescence, a harvest of shoot biomass was made by cutting vegetation at ground or mulch level and weighing the harvest. Estimates of the cost of materials were made from the retail prices paid for herbicides and alternative materials used in this investigation. Labor was not included in the estimates; however, the time to apply the various materials was recorded, and a projection of the hand labor needed to treat 1 mile of highway was made.

EXPERIMENT 2. The second experiment investigated the effects of mowing of roadside vegetation on the efficacy of herbicides applied to plots under guardrails at a site near Exit 24 of Interstate 91 (Table 3). This site was not sprayed with herbicide in 2004 , and the vegetation at the site was principally perennial grasses [quackgrass (Agropyron repens Beauv.) and tall fescue (Festuca arundinacea Schreb.)], each about 12 inches tall. Mowing occurred $\mathrm{l} d$ before the herbicide treatments were applied. Mowing was to 4 -inch height by a hand-held, plastic-string trimmer. The herbicide treatments were applied in mid-July 2005, as described above in Expt. 1 for the liquid herbicides. Treatments were evaluated for efficacy by visual indexing
(Table 2) at 2, 6, and 10 weeks after treatment. The evaluation at 2 weeks after treatment was at a time perceived by the investigators as being a peak expression of efficacy of all herbicidal treatments. The evaluation at 6 weeks rated the efficacy at a time at which the alternative herbicides were waning in their effects, and the evaluation at 10 weeks was at the end of the growing season at the end of September. The experiment was in a randomized-complete block design with a split-plot treatment arrangement with mowing treatments as the main plots and with herbicide treatments randomized within the mowing treatments. Plots were $4 \mathrm{ft}$ wide by $20 \mathrm{ft}$ long under guardrails along the highway.

Table 3. Material, product name, concentrations of formulations, and rates of application of alternative and conventional herbicides applied to roadside vegetation under guardrails with or without mowing pretreatment in Expt. 2 in 2005.

\begin{tabular}{|c|c|c|c|}
\hline \multirow[b]{2}{*}{ Material } & \multirow[b]{2}{*}{ Product $^{\mathrm{z}}$} & \multicolumn{2}{|c|}{ Application of product } \\
\hline & & Concn $(\%)^{y}$ & Rate (qt/1000 $\mathrm{ft}^{2}$ a.i. $)^{\mathrm{x}}$ \\
\hline Clove oil & Matran EC & 20 & 0.67 \\
\hline Citric acid & AllDown & 100 & 0.34 \\
\hline Pelargonic acid & Scythe & 7 & 0.025 \\
\hline Glufosinate-ammonium & Finale & 1.3 & 0.018 \\
\hline Glyphosate & RoundupPro & 1.0 & 0.067 \\
\hline
\end{tabular}

${ }^{z}$ Matran EC ( $50 \%$ clove oil; EcoSMART, Franklin, TN), AllDown ( $5 \%$ citric acid and $0.2 \%$ garlic; Green Chemistry Herbicide; SummerSet Products, Eagan, MN); Scythe (57\% pelargonic acid; Mycogen, San Diego), Finale (20\% glufosinate-ammonium; Bayer, Research Triangle Park, NC), RoundupPro (41\% glyphosate; Monsanto, St. Louis).

'Concentration (by volume) of commercial formulation in water.

${ }^{\mathrm{x}} \mathrm{lqt} / 1000 \mathrm{ft}^{2}=101.8646 \mathrm{~L} \cdot \mathrm{ha}^{-1}$.

Table 4. Efficacy as assessed by a visual index of actions of mulches or corn gluten meal on control of roadside vegetation under guardrails and at three stages of plant development as measured by time following treatments in 2 years of research in Expt. 1.

\begin{tabular}{|c|c|c|c|}
\hline \multirow[b]{2}{*}{ Treatment } & \multicolumn{3}{|c|}{$\begin{array}{l}\text { Visual index (0-10 scale) with time } \\
\text { after application of treatments }\end{array}$} \\
\hline & 2 weeks & 5 weeks & 10 weeks \\
\hline \multicolumn{4}{|l|}{2005} \\
\hline Bark mulch & $9.0 \mathrm{a}^{\mathrm{y}}$ & $9.5 \mathrm{a}$ & $9.3 \mathrm{a}$ \\
\hline Woodchip mulch & $10.0 \mathrm{a}$ & $9.5 \mathrm{a}$ & $9.3 \mathrm{a}$ \\
\hline Corn gluten meal & $8.8 \mathrm{a}$ & $4.3 \mathrm{~b}$ & $0 \mathrm{~b}$ \\
\hline \multicolumn{4}{|l|}{2006} \\
\hline Bark mulch & $7.7 \mathrm{a}$ & $5.3 \mathrm{~b}$ & $7.3 \mathrm{a}$ \\
\hline Woodchip mulch & $6.0 \mathrm{~b}$ & $5.7 \mathrm{~b}$ & $7.7 \mathrm{a}$ \\
\hline Bark + clove oil & $9.0 \mathrm{a}$ & $8.0 \mathrm{a}$ & $8.3 \mathrm{a}$ \\
\hline Woodchip + clove oil & $9.0 \mathrm{a}$ & $9.0 \mathrm{a}$ & $8.0 \mathrm{a}$ \\
\hline Corn gluten meal & $10.0 \mathrm{a}$ & $8.0 \mathrm{a}$ & $3.0 \mathrm{~b}$ \\
\hline
\end{tabular}

${ }^{\mathrm{z}}$ Mulches were not reapplied in 2006. Dates are about 1 July, the first week of August, and the second weed of September in each year. Rating was on a scale of 0 (no control) to 10 (complete control) of vegetation (See Table 2).

'Within years, means followed by different letters in columns are significantly different by least significant difference at $P=0.05$. 
Table 5. End-of-season biomass of shoots of roadside vegetation treated for 2 years with alternative and conventional herbicides under guardrails in Expt. 1.

\begin{tabular}{llr}
\hline & \multicolumn{2}{c}{ Weed biomass $\left(\mathbf{g} \cdot \mathbf{m}^{-2} \mathbf{F W}\right)^{\mathbf{z}}$} \\
\cline { 2 - 3 } Treatment & $\mathbf{2 0 0 5}$ & $\mathbf{2 0 0 6}$ \\
\hline Citric-acetic acids & $700 \mathrm{a}^{\mathrm{y}}$ & $514 \mathrm{~b}$ \\
Clove oil & $636 \mathrm{abc}$ & $445 \mathrm{~b}$ \\
Corn gluten meal & $900 \mathrm{a}$ & $1,552 \mathrm{a}$ \\
Pelargonic acid & $668 \mathrm{abc}$ & $\mathbf{5 2 1 \mathrm { b }}$ \\
Glufosinate-ammonium & $368 \mathrm{~cd}$ & $0 \mathrm{c}$ \\
Glyphosate & $383 \mathrm{bcd}$ & $0 \mathrm{c}$ \\
Mulches & $154 \mathrm{~d}$ & $362 \mathrm{~b}$ \\
Mulches + clove oil spray & $\mathrm{N} / \mathrm{A}$ & $366 \mathrm{~b}$ \\
Burning & $880 \mathrm{a}$ & $359 \mathrm{~b}$ \\
Untreated & $800 \mathrm{a}$ & $546 \mathrm{~b}$
\end{tabular}

${ }^{\mathrm{z}}$ Harvests were in the last week of September in each year; $1 \mathrm{~g} \cdot \mathrm{m}^{-2}=0.0033 \mathrm{oz} / \mathrm{ft}^{2}, \mathrm{FW}=$ fresh weight.

'Within columns, means followed by different letters are significantly different by least significant difference at $P=$ 0.05 .

contributed to the efficacy of the mulches in 2005. In 2006, visual indexing (Table 4) suggested that the mulches continued to give good control of vegetation and that spraying with clove oil improved the control. However, in 2006, suppression of the end-of-season weed biomass by the mulches was not better than any the other alternative treatments except the use of CGM. The high biomass in the mulched plots with or without spraying in 2006 was due to the large weights of a few weeds; however, visual indexing indicated that the plots were relatively clean. Spraying of mulches with clove oil gave no improvement in suppression of weed biomass at the end of the season harvest (Table 5) but improved the appearance of the plots. Conventional chemical herbicides, glyphosate and glufosinate-ammonum (Finale; Bayer, Research Triangle Park, NC), gave good control of vegetation throughout the season but had a weed biomass that was larger than that in the mulched plots in 2005 (Table 5). In 2006, glyphosate and glufosinate-ammonium performed better than the mulches, and no harvestable biomass was present in 2006 with these herbicidal treatments. Perhaps 2 years of treatment with these conventional herbicides contributed to their effectiveness in 2006. Pelargonic acid (Scythe; Mycogen, San Diego) gave good weed control early on (about July 1 or 2 weeks after treatment) and midseason (about Aug. 1 or 6 weeks after treatment), but the efficacy of this treatment was dissipated by 10 weeks (about Sept. 1) after treatment and at harvest in late September (Table 5; Fig. 1). In the end, pelargonic acid was no better than any other alternative herbicide tested. Pelargonic acid is a naturally occurring chemical, but because Scythe is made from other fatty acids, it is not on a list of organic substances prepared by OMRI. Organic herbicides formulated from clove oil or from citric acid and acetic acid blends (Ground Force; Abby Laboratories, Ramsey, MN; Blackberry and Brush Block, Brush Weeds \& Grass; Greenergy, Brookings, OR) had little efficacy at any time during the growing season (Fig. $1)$, and weed biomass in these plots approached or equaled that of the untreated plot (Table 5). Torch burning gave good control of vegetation in the early and midseason, but lost its effectiveness by fall. Plots treated with CGM also exhibited control during the early and midseason. However, this effect is considered to be due to the burning pretreatment to prepare the plots for application of the meal. The efficacy of the meal was gone by the 10 -week rating and fall harvest. Weed biomass from the plots receiving the CGM was the largest with any treatment, and plants in these plots were growing vigorously in September with no signs of senescence.

Mowing AND ALternative HERBICIDES (EXPT. 2). The effect of mowing on the growth of vegetation was not significant, and mowing did not interact with the herbicidal treatments or dates (Table 6). Clove oil (Matran) and citric acid (AllDown; SummerSet Products, Eagan, MN) had weak efficacy on vegetation control at all dates of assessment $(2,6$, or

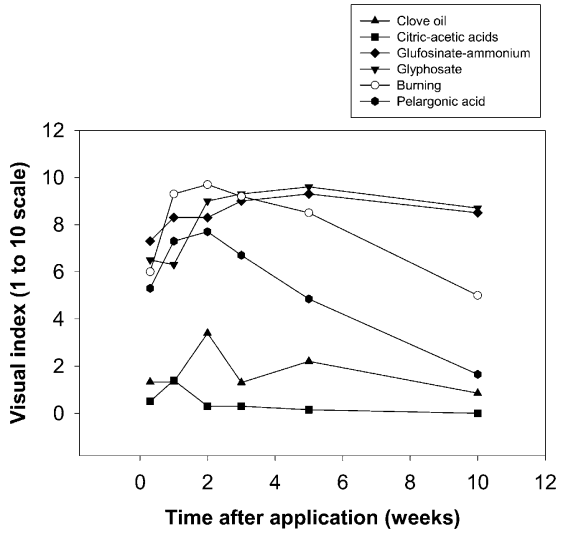

Fig. 1. Time-based efficacy of treatments of alternative herbicides, burning, and conventional herbicides for management of roadside vegetation as assessed by visual indexing.

Composite of results by dates in 2005 and 2006. Years are not distinguished by data points. Rating was on a scale of 0 (no control) to 10 (complete control) of vegetation (see Table 2 ). The dates after treatment range from $3 \mathrm{~d}$ to 10 weeks from mid-June to the first week of September in each year.

10 weeks after treatments). The maximum rating of these materials was about 2 on the visual index scale (Table 2). The efficacy of pelargonic acid (Scythe) was initially moderate but lessened with time at and after 6 weeks. Vegetation control with glyphosate (RoundupPro) and glufosinateammonium (Finale) was strong on all dates in this experiment, approaching or reaching complete suppression of vegetation.

\section{Discussion}

In both experiments, all alternative herbicide applied as sprays showed a decline in efficacy with time after application, indicating that repeated applications of these materials would be necessary to effect control. The alternative herbicides control vegetation through foliar contact, thereby killing or injuring the vegetation exposed to the herbicide. These herbicides are not translocated to the crowns, roots, or other plant parts; hence, regrowth can occur. Several formulations of citric acid-acetic acid were evaluated. In diluted formulations, none of these materials had potential for suppression of growth of vegetation. Formulations of citric acidacetic acid must be used at full-strength (about $20 \%$ a.i.) without dilution with 
water to impart suppression of vegetative growth, although some label recommendations are for use at $25 \%$ to $33 \%$ strength of the concentrated formulation. The efficacy of pelargonic acid was initially moderate, about $60 \%$ suppression of growth soon after application, but lessened with time after 6 weeks with essentially no control being apparent at the end of the growing season (10 weeks after application). Repeated applications of the alternative herbicides apparently will be needed for season-long control of vegetation, perhaps at intervals of every 6 weeks or more often. The conventional herbicides (glyphosate and glufosinate- ammonium) are translocated throughout the plants and gave systemic killing with control for at least 10 weeks in these experiments.

The costs of purchasing the alternative herbicides will be much more than the use of conventional herbicides (Table 7; Wilen and Boise, 2008; Young, 2004). The costs of materials shown (Table 7 ) are retail prices paid for materials in this research. Labor costs also will be higher for the alternative herbicides because multiple applications, perhaps three or more per year, will be needed to bring about season-long control of vegetation. Young (2004) suggested five applications of

Table 6. Efficacy as assessed by a visual index of actions of conventional and alternative herbicides in management of mowed or unmowed vegetation at three stages of plant development measured by time following treatments under guardrails during Expt. 2.

\begin{tabular}{|c|c|c|c|c|c|c|}
\hline \multirow[b]{3}{*}{ Treatment } & \multicolumn{6}{|c|}{$\begin{array}{c}\text { Visual index }(0-10 \text { scale }) \text { for dates after } \\
\text { treatment and mowing regime }\end{array}$} \\
\hline & \multicolumn{2}{|c|}{2 weeks } & \multicolumn{2}{|c|}{6 weeks } & \multicolumn{2}{|c|}{10 weeks } \\
\hline & Mow & $\mathrm{Unm}^{\mathrm{y}}$ & $\overline{\text { Mow }}$ & Unm & Mow & Unm \\
\hline Untreated & $0 c^{x}$ & $0 \mathrm{~d}$ & $0 \mathrm{~b}$ & $0 \mathrm{c}$ & $0 \mathrm{~b}$ & $0 \mathrm{~b}$ \\
\hline Clove oil & $2.0 \mathrm{bc}$ & $2.3 \mathrm{c}$ & $1.3 \mathrm{~b}$ & $2.0 \mathrm{bc}$ & $0.3 \mathrm{~b}$ & $0.3 \mathrm{~b}$ \\
\hline Pelargonic acid & $4.0 \mathrm{~b}$ & $6.3 \mathrm{~b}$ & $2.0 \mathrm{~b}$ & $4.3 \mathrm{~b}$ & $0 \mathrm{~b}$ & $0.7 \mathrm{~b}$ \\
\hline Citric acid & $2.0 \mathrm{bc}$ & $2.0 \mathrm{c}$ & $1.3 \mathrm{~b}$ & $2.0 \mathrm{bc}$ & $1.0 \mathrm{~b}$ & $0.3 \mathrm{~b}$ \\
\hline Glyphosate & $9.3 \mathrm{a}$ & $10.0 \mathrm{a}$ & $9.8 \mathrm{a}$ & $10.0 \mathrm{a}$ & $9.2 \mathrm{a}$ & $10.0 \mathrm{a}$ \\
\hline $\begin{array}{l}\text { Glufosinate- } \\
\text { ammonium }\end{array}$ & $9.5 \mathrm{a}$ & $10.0 \mathrm{a}$ & $8.8 \mathrm{a}$ & $9.5 \mathrm{a}$ & $8.0 \mathrm{a}$ & $9.2 \mathrm{a}$ \\
\hline Mean $^{w}$ & 4.5 & 5.1 & 3.9 & 4.6 & 3.1 & 3.4 \\
\hline
\end{tabular}

acetic acid per year. In practice, mechanized methods of applications will be used, but in this research, the hand labor required for one application of the sprayed herbicides or the CGM was about $8 \mathrm{~h} / \mathrm{mile}$ and for the mulches was $88 \mathrm{~h} / \mathrm{mile}$.

The mulches (bark and woodchip) gave season-long control of vegetation and in the first year had the least end-of-season weed biomass among the treatments employed. In the second year of research, mulches were not reapplied, and the initial application gave only limited control of vegetation; however, in the second year, a treatment with an alternative herbicide improved control in the early season. Spraying of mulched plots was not needed to manage vegetation with this treatment in the first year of investigation. Mulching, although highly effective in weed management, is the most costly for purchase of material (Table 7) and is labor intensive.

CGM had little efficacy for use in management of roadside vegetation. This material is applied for suppression of emerging vegetation from germination of seeds in the soil. It is not phytotoxic to growing plants. Burning gave adequate preparation of sites for use of the meal, but the meal did not suppress growth of emerging vegetation. In most cases, CGM, with about $10 \%$ nitrogen by weight, was a nitrogen fertilizer that stimulated growth of vegetation throughout the growing season and

Table 7. Estimates of costs of materials to treat a mile of highway with alternative materials or conventional herbicides for 1 year based on the number of applications per year, the total amounts of materials applied, and unit cost of the materials

\begin{tabular}{|c|c|c|c|c|c|}
\hline \multirow[b]{2}{*}{ Material } & \multirow{2}{*}{$\begin{array}{c}\text { Applications / } \\
\text { year }\end{array}$} & \multicolumn{2}{|c|}{ Total applied ${ }^{\mathrm{z}}$} & \multirow{2}{*}{$\begin{array}{c}\text { Cost } \\
(\$ / \text { unit })^{y}\end{array}$} & \multirow{2}{*}{$\begin{array}{l}\text { Cost }(\$ / \text { mile } \\
\text { of highway })^{\mathrm{x}}\end{array}$} \\
\hline & & a.i./mile & product $/ \mathrm{mile}$ & & \\
\hline $\begin{array}{l}\text { Citric-acetic } \\
\text { acid group }\end{array}$ & 3 & $8-14 \mathrm{qt}$ & $40-142 \mathrm{qt}$ & $\$ 3.50-\$ 9 / \mathrm{qt}$ & $\$ 270-570$ \\
\hline Clove oil & 3 & $7 \mathrm{qt}$ & $14 \mathrm{qt}$ & $\$ 16 / q t$ & $\$ 220$ \\
\hline Corn gluten meal & 1 & $\mathrm{n} / \mathrm{a}$ & $1,270 \mathrm{lb}$ & $\$ 0.70 / \mathrm{lb}$ & $\$ 890$ \\
\hline Pelargonic acid & 3 & 5.3 & $9.3 \mathrm{qt}$ & $\$ 12.50 / \mathrm{qt}$ & $\$ 120$ \\
\hline Bark mulch & 1 & $\mathrm{n} / \mathrm{a}$ & 195 yard $^{3}$ & $\$ 22 /$ yard $^{3}$ & $\$ 4,300$ \\
\hline Woodchip mulch & 1 & $\mathrm{n} / \mathrm{a}$ & 195 yard $^{3}$ & $\$ 18 /$ yard $^{3}$ & $\$ 3,500$ \\
\hline
\end{tabular}

${ }^{\mathrm{z}} \mathrm{l} \mathrm{qt} / \mathrm{mile}=0.5880 \mathrm{~L} \cdot \mathrm{km}^{-1}, \mathrm{l} \mathrm{lb} / \mathrm{mile}=0.2818 \mathrm{~kg} \cdot \mathrm{km}^{-1}, \mathrm{l} \mathrm{yard}^{3} / \mathrm{mile}=0.475 \mathrm{l} \mathrm{m}^{3} \cdot \mathrm{km}^{-1}, \mathrm{n} / \mathrm{a}=$ not applicable.

${ }^{y}$ Retail prices paid for products in this investigation; $\$ 1.00 / \mathrm{qt}=\$ 1.0567 / \mathrm{L}, \$ 1.00 / \mathrm{lb}=\$ 2.2046 / \mathrm{kg}, \$ 1.00 / \mathrm{yard}^{3}=\$ 1.3080 / \mathrm{m}^{3}$.

${ }^{x}$ Includes only the cost of materials $(\$ 1.00 / \mathrm{mile}=\$ 0.6214 / \mathrm{km})$. The labor for hand application in this investigation was $8 \mathrm{~h} / \mathrm{mile}\left(5.0 \mathrm{~h} \cdot \mathrm{km} \mathrm{m}^{-1}\right)$ of highway for one application of the sprayed materials or corn gluten meal and $88 \mathrm{~h} / \mathrm{mile}\left(54.7 \mathrm{~h} \cdot \mathrm{km}^{-1}\right)$ for application of the mulches. Application was on a 4 -ft-wide (1.2 m) strip under guardrails. 
that prolonged the season of growth past that of untreated vegetation.

\section{Literature cited}

Akhtar, Y., M.B. Isman, and Y.-R. Yeoung. 2008. Comparative bioactivity of selected extracts from Meliaceae and some commercial botanical insecticides against two noctuid caterpillars, Trichoplusia ni and Pseudaletia unipuncta. Phytochem. Rev. 7(1):77-88.

Arboleya, J.E., J. Masabni, M.G. Particka, and B.H. Zandstra. 2005. Identification of preharvest desiccants for use in onion. HortTechnology 15(4):808-811.

Ascard, J. 1994. Dose-response models for flame weeding in relation to plant size and density. Weed Res. 34(5):377-385.

Ascard, J. 1995. Effects of flame weeding on weed species at different developmental stages. Weed Res. 35(5): 397-411.

Ayeni, A.O., B.A. Majek, J.R. Johnson, and R.G. Obal. 1999. Container nursery weed control: Bittercress, groundsel, and oxalis. Rutgers Coop. Ext. Fact Sheet 939.

Barker, A.V. and P.C. Bhowmik. 2001. Weed control with crop residues. J. Crop Prod. 4(2):163-183.

Barker, A.V. and R.G. Prostak. 2008. Alternative herbicides research, Massachusetts Highway Dept., Office Transportation Planning, Rpt. SPRII03.23.

Barker, A.V. and T.A. O'Brien. 1995. Weed control in establishment of wildflower sods and meadows. Proc. Northeast Weed Sci. Soc. 49:56-60.

Boyd, N.S. and E.B. Brennan. 2006. Burning nettle, common purslane, and rye response to a clove oil herbicide. Weed Technol. 20(3):646-650.

Chase, C.A., J.A. Scholberg, and G.E. MacDonald. 2004. Preliminary evaluation of nonsynthetic herbicides in organic orange production. Proc. Florida State Hort. Soc. 117:135-138.

Christians, N. 2007. Corn gluten meal research page. 1 July 2008. <http:// www.hort.iastate.edu/gluten/>.

Christians, N.E. 2002. Use of corn gluten meal as a natural pre-emergent weed control. Turfgrass Trends 11(1):tl4-tl6.

Coleman, R. and D. Penner. 2006. Desiccant activity of short chain fatty acids. Weed Technol. 20(2):410-415.

Doll, J. 2002. Acetic acid (vinegar) for weed control. 24 June 2008. <http:// ipcm.wisc.edu/uw_weeds/extension/ articles/aceticacid.htm>.
Duke, S.O. 1990. Natural pesticides from plants, p. 511-517. In: J. Janick and J.E. Simon (eds.). Advances in new crops. Timber Press, Portland, OR.

Eshenaur, B., A. Senesac, I. TsontakisBradley, and L. Weston. 2007. Weed suppressive groundcovers. I July 2008. <http://nysipm.cornell.edu/factsheets/ n_gh/groundcovers.pdfs.

Henderson, K. 2000. Integrated roadside vegetation management: A quick glance around the country. Erosion Control Apr. 2000. 4 June 2008. <http://www.forester.net/ec_0004_integrated.html>.

Kishore, G.K., S. Pande, and S. Harish. 2007. Evaluation of essential oils and their components for broad-spectrum antifungal activity and control of late leaf spot and crown rot diseases in peanut. Plant Dis. 91(4):375-379.

Liu, D.L. and N.E. Christians. 1994. Isolation and identification of root-inhibiting compounds from corn gluten hydrosylate. J. Plant Growth Regul. 13:227-230.

Liu, D.L. and N.E. Christians. 1996. Bioactivity of a pentapeptide isolated from corn gluten hydrosylate on Lolium perenne L. J. Plant Growth Regulat. 15:13-17.

Johnson, A. 2000. Best practices handbook on roadside vegetation management. Minnesota Technology Transfer/Local Technical Assistance Program (LTAP). Center for Transportation Studies, University of Minnesota, Minneapolis.

Johnson, E., T. Wolf, B. Caldwell, R. Barbour, R. Holm, and K. Sapsford. 2004. Efficacy of vinegar (acetic acid) as an organic herbicide. Agriculture Development Fund (ADF) Project No. 20020202 and Agriculture and AgriFood Canada (AAFC) Project A03637, Final Report. University of Saskatchewan, Saskatoon. 15 Oct. 2008. <http://www. agr.gov.sk.ca/apps/adf/adf_admin/ reports/20020202.pdf>.

Meyer, S.L.F., D.K. Lakshman, I.A. Zasada, B.T. Vinyard, and D.J. Chitwood 2008. Dose-response effects of clove oil from Syzygium aromaticum on the rootknot nematode Meloidogyne incognita. Pest Manag. Sci. 64(3):223-229.

Organic Materials Research Institute. 2008. OMRI products list. 16 Oct. 2008. <http://omri.org/OMRI_ products_list.php $>$.

Owens, K. 1999. The right way to vegetation management. Pesticides and You 19(1):9-17.

Radhakrishnan, J., J. Teasdale, and C. Coffman. 2003. Agricultural applications of vinegar. Proc. Northeast Weed Sci. Soc. 57:63-64.
Rifai, M.N., T. Astatkie, M. Lacko-Bartosova, and J. Gadus. 2002. Effect of two different thermal units and three types of mulch on weeds in apple orchards. J. Environ. Eng. Sci. 1(5):331-338.

Tworkoski, T. 2002. Herbicide effects of essential oils. Weed Sci. 50(4):425-431.

Steel, R.G.D. and J.A. Torrie. 1980. Principles and procedures of statistics. 2nd ed. McGraw Hill, New York.

Stelljes, K.B. and M. Wood. 2000. Foreign agents imported for weed control. Agr. Res. March:4-9.

van der Wolf, J.M., Y. Birnbaum, P.S. van der Zouwen, and S.P.C. Groot. 2008. Disinfection of vegetable seed by treatment with essential oils, organic acids and plant extracts. Seed Sci. Technol. 76(1):76-88.

Webber, C.L., III and J.W. Shrefler. 2007. Organic weed control with vinegar: Application volumes and adjuvants. Proc. Hort. Ind. Show 26:149-151.

Weeden, C.R., A.M. Shelton, and M.P. Hoffman. 2008. Biological control: A guide to natural enemies in North America. I July 2008. <http://www.nysaes. cornell.edu/ent/biocontrol/>.

Wilen, C. and P. Boise. 2008. Evaluation of least-toxic herbicides. I July 2008. <http://ucce.ucdavis.edu/files/filelibrary/ 2017/19351.ppt>.

Windgolz, M. (ed.). 1983. The Merck Index. Merck, Rahway, NJ.

Yandoc-Abeles, C.B., E.N. Rosskopf, and R. Charudatten. 2006a. Plant pathogens at work: Progress and possibilities for weed control. Part 1. Classical vs. bioherbicidal approach. I July 2008. <http:// www.apsnet.org/online/feature/ weedl $/>$.

Yandoc-Abeles, C.B., E.N. Rosskopf, and R. Charudatten. 2006b. Plant pathogens at work: Progress and possibilities for weed control. Part 2. Improving weed control efficacy. I July 2008. <http:// www.apsnet.org/online/feature/ weed $2 />$.

Yang, Y.C., H.S. Lee, J.M. Clark, and Y.J. Ahn. 2004. Insecticidal activity of plant essential oils against Pediculus humanus capitis (Anoplura: Pediculidae). J. Med. Entomol. 41(4):699-704.

Young, S.L. 2002. Exploring alternative methods for vegetation control and maintenance along highways. 29 Oct. 2008. <http://www.dot.ca.gov/hq/LandArch/ research/docs/exploring.pdfs.

Young, S.L. 2004. Natural products for control of annual vegetation along roadsides. Weed Technol. 18(3):580-587. 